\title{
The Intergenerational Mobility of Income: A Study Applied to the Spanish Case (2005-2011)
}

\author{
Natalia Sánchez Martín ${ }^{1} \cdot$ Carmelo García-Perez ${ }^{1}$ (1)
}

Accepted: 24 November 2021 / Published online: 12 January 2022

(c) The Author(s) 2022

\begin{abstract}
Intergenerational income mobility has attracted the interest of many economists for-among other reasons-its role as a mechanism for reducing inequalities and achieving equal opportunities. In this paper, we analyse the intergenerational mobility of income in Spain in the years 2005 and 2011, located at different phases of the economic cycle. We use proxy variables (the economic situation of the household during the adolescence of the informant and the educational level achieved by parents) to study intergenerational income mobility, because there are not extant surveys with income information from parents and their descendants when they are part of a different household. With these variables, we try to verify the existence and degree of mobility by analysing different methodologies. The results suggest the existence of mobility in the two studied years, although a trend towards a reduction in intergenerational mobility is confirmed, already detected by other authors.
\end{abstract}

Keywords Intergenerational income mobility $\cdot$ Economic situation $\cdot$ Educational level $\cdot$ Spain

\section{Introduction}

Intergenerational income mobility, understood as the change in the income level of children compared with their parents or the change in income between different generations, has aroused the interest of economists as a way to reduce inequality and improve the living conditions of the population, achieving economic progress and stable and sustainable growth in social terms. The existence and intensity of income mobility is also an indicator of equality of opportunities among people from families with different income levels. Likewise, expectations of low mobility reduce hope and ambition, perpetuating the absence of mobility (Narayan et al., 2018).

Mobility studies analyse the individual change of position and income level between two different periods (intragenerational mobility) as well as the income-level change between children and their parents or previous generations (intergenerational mobility). Mobility can be ascending or descending; that is, some individuals' income levels improve

Carmelo García-Perez

carmelo.garcia@uah.es

1 Universidad de Alcalá, Plaza de la Victoria, 8, 28802 Alcalá de Henares, Spain and others worsen. Mobility can also be conceived as both absolute and relative.

Mobility studies are complementary to studies focusing on individual income inequality and poverty. In Spain, research on mobility is scarce and the studies that have been conducted have mainly focused on intragenerational income mobility (Ayala \& Sastre, 2002; Cantó, 2000; Prieto et al., 2002). Among the intergenerational mobility studies, Sánchez (2004) analysed intergenerational income mobility in the 1980s and 1990s.

As a result of the economic downturn experienced in Spain since the outbreak of the international economic crisis in 2008, the topic of this research is becoming increasingly important. After the Great Recession, the possibility of children improving their parents' standard of living was reduced (Ayala, 2016). Other studies, such as that by the OECD (2018), have concluded that it takes four generations, on average, for a Spaniard born into a low-income family to achieve an average income level.

The crisis has also ushered in a reduction in public spending on education, causing "a greater probability that access to education opportunities will be dependent on family environment and will be more unequal" (Tormo et al., 2016, p. 302). These economic policy measures affect mobility, complicating the upward social mobility of children from 
low-income families. As indicated by Requena (2016), achieving a higher level of education promotes upward social mobility.

As we have mentioned, in Spain, there are no yearly samples that simultaneously provide the incomes of parents and the incomes of children who have left the household. However, it is possible to study intergenerational income mobility through proxy variables for parents' income with data from the Intergenerational Transmission of Poverty module included in the Living Conditions Survey (LCS) in 2005 and 2011. This module provides information on the employment and academic background of parents as well as the economic and social household situation. Using this source, we can estimate the transferability of skills and abilities by comparing the information available from children and their parents.

Given the limitations of the available data for Spain, we conducted a study that incorporated different ways of verifying the existence (or otherwise) of intergenerational mobility and quantified its intensity as an alternative to a strict analysis of income data from parents and children. In fact, we analysed the intergenerational income mobility in Spain using proxy variables for the parents' income, which allowed us to carry out a study from different perspectives. The objective was therefore to obtain relevant information that allowed us to ascertain whether there is any mobility of income between parents and children in Spain or whether, on the contrary, economic status is determined by birth. To conduct this analysis, we used different techniques based on estimates of econometric models and the construction of transition matrices and mobility indices. The different analyses carried out allowed us to conclude that, in Spain, there was intergenerational mobility in 2005 and 2011 for both education and income levels, although there was a reduction in intergenerational mobility during that time frame.

The structure of the paper is as follows. In the next section, we review the literature on intergenerational income mobility. Subsequently, both the data and the methodology are presented, followed by the results of the study. Finally, we conclude with a summary of the main conclusions drawn from the study.

\section{Literature Review}

\section{Cross-Country Evidence}

The first estimates of intergenerational income mobility were conducted with data from the United Kingdom. Atkinson (1981) proposed the estimation of the model using OLS according to the following expression:

$\log E_{t}^{i}=\beta \log E_{(t-1)}^{i}+u_{t}^{i}$ where $E_{t}^{i}$ are the earnings of individual i in generation t, $E_{t-1}^{i}$ are the earnings of individual $\mathrm{i}$ in generation $\mathrm{t}-1$, and $\beta$ is the coefficient that summarizes the degree to which the earnings distribution can be perpetuated from one generation to another-that is, the degree of mobility. The $\beta$ coefficient has been constructed in this way from the very earliest studies as the reference measure in the intergenerational mobility literature. $u_{t}^{i}$ is the error term, and it is normally distributed with 0 mean and $\sigma^{2}$ variance.

Subsequently, Becker and Tomes (1986) studied intergenerational mobility in the United States using OLS regression, in which the dependent variable was the child's annual earnings. In Appendix Table 11, we present a summary of the estimation models used in different mobility studies. In general, different authors have used two types of methodology: econometric models that explain children's income levels based on variables relating to their parents and probability transition matrices between different statuses of parents and children.

In addition to the studies in Appendix Table 11 focusing on income mobility in a single country, there is a line of comparative studies between European countries and the United States. We highlight Jäntti et al. (2006), who undertook a comparison of intergenerational income mobility between the US, Germany, Finland, Norway, the United Kingdom, and Sweden. In more recent works, some authors have used correlation coefficients by range, such as Bratberg et al. (2017) and Corak et al. (2014), or intergenerational mobility curves, incorporating a variation proposed by Aaberge and Mogstad (2014). Finally, Nilsson (2019) developed a new non-parametric method for studying intergenerational income mobility based on correlation curves.

Most of the aforementioned studies focused on developed countries, such as the US, the UK, Nordic countries, and some other European countries. Countries in southern Europe are not included among the latter because of the lack of availability of adequate survey data for the study of intergenerational income mobility.

\section{The Spanish Case}

The first studies on intergenerational mobility in Spain were carried out in the field of sociology. In the field of economics, as Cantó (2000) argued, not much literature has examined mobility as the bulk of the research has focused mainly on the study of poverty and inequality but without comparisons between generations.

Among the few existing papers, ${ }^{1}$ Cantó (2000) conducted an interesting study of mobility and concluded that income

\footnotetext{
1 Ayala and Sastre (2002) made a compilation of existing approaches to the study of intergenerational mobility.
} 
mobility increased in the period from 1985 to 1991 and decreased from 1991 to 1992. Sanchez (2004) analysed the intergenerational mobility of education and income and concluded that mobility increased from 1980 to 1990 as the earnings correlation coefficient between parents and children changed from 0.328 to 0.208 .

Güell et al. (2007) analysed mobility in Catalonia using a novel method based on the joint distribution of economic results and surnames. Their main finding was that mobility decreased among the different generations in the twentieth century. Using data from the European Union Households Panel, Pascual (2009) analysed intergenerational income mobility and determined that children's income depends on the socioeconomic status of their parents.

Cervini (2015, p. 812) estimated the elasticity of sons' and daughters' incomes as a measure of intergenerational income mobility using Spanish data from 2005 and concluded that the mobility of sons and daughters in Spain is "similar to that of France, lower than that of the Nordic countries and Great Britain and greater than that of Italy and the United States". In Spain, educational mobility has also been studied by different authors. Sánchez (2004) concluded that Spain is one of the countries in Europe with more educational mobility. More recently, Gil et al. (2017) concluded that the flow of educational levels between generations has increased and that it promotes equal opportunities in educational reforms.

Comparing the papers conducted on intergenerational income mobility in Spain, we can conclude that the results change depending on the year of study and the methodology used. However, in general, it could be concluded that the different studies point to a trend towards decreasing mobility, especially since the 1990 s, which could continue and become more pronounced in the years of economic crisis that are considered in this study. This hypothesis about the decrease in mobility is also supported by the studies by Bárcena and Moro (2013) and Celorrio (2013), which concluded that, in the years of economic crisis and budget adjustments, mobility has decreased in most countries due to the reduction of resources allocated to policies that favour equal opportunities. In this article, we will therefore investigate whether this trend towards the reduction of income mobility has continued and even whether it has been accentuated during the period studied (2005-2011).

\section{Data}

The analysis of intergenerational income mobility, in a strict sense, requires surveys that collect the wages or incomes of parents and children, which are not available in Spain. However, the data available in the intergenerational poverty transmission module of the LCS allow us to estimate mobility coefficients based on proxy variables for parents' income or wages, such as their educational level or other qualitative variables that define the economic situation of an individual during adolescence.

The LCS is part of the European Statistics on Income and Living Conditions (EU-SILC) instrument, coordinated by Eurostat, and provides household and individual information. In 2005 and 2011, the survey included an intergenerational poverty transmission module, which collected households' and parents' characteristics for the period during which the interviewee was a teenager (approximately 14 years old) to analyse the influence of the family environment on the interviewee's development. This module was aimed at people aged between 25 and 65 (59 in the 2011 LCS).

The information that we obtain about the situation of the family home when the adult was a teenager is as follows: household composition, number of siblings, year of birth, highest level of education attained, main occupation, labour status of the father/mother, and financial situation of the household. The information provided by the module described does not allow us to obtain parents' income information, but we do obtain variables that are determinants of permanent income (occupation, employment status, and educational level attained by parents). The concept of income that we use in this paper includes the income of employees as well as self-employed income. This concept of income corresponds to disposable income - that is, net income after direct taxes and social security contributions.

Table 1 shows the percentage of individuals in each of the categories of the variables used in the study. Among other facts, it can be observed that the predominant educational level of the parents is low, with $60.54 \%$ in 2005 and $80.06 \%$ in 2011 . In the case of mothers, the situation is similar, so most mothers also have a low educational level (62.75\% in 2005 and $83.26 \%$ in 2011). In both cases, an improvement is observed in the educational levels achieved by parents in the second year considered. In general terms, fathers also have a higher educational level than mothers. Regarding the educational level of the children, they obviously have a better situation than their parents, a consequence of the great changes in the country's educational system and its political and economic situation.

In 2005, the more frequent economic situation of households in adolescence was a good situation (55.97\%). In 2011, the intermediate economic situation was predominant with $58.41 \%$; however, we must emphasize that, in 2011, the proportion of individuals with a bad economic situation at home during their adolescence decreased from $23.83 \%$ to $13.7 \%$. 
Table 1 Descriptive statistics

\begin{tabular}{|c|c|c|}
\hline & 2005 & 2011 \\
\hline Mean logarithm of income & 7.0999 & 9.429 \\
\hline \multicolumn{3}{|l|}{ Children's educational level } \\
\hline Uneducated & $2.36 \%$ & $2.57 \%$ \\
\hline Low level & $51.25 \%$ & $45.16 \%$ \\
\hline Medium level & $20.96 \%$ & $22.04 \%$ \\
\hline High level & $25.42 \%$ & $30.23 \%$ \\
\hline \multicolumn{3}{|l|}{ Fathers' educational level } \\
\hline Uneducated & $25.96 \%$ & $4.63 \%$ \\
\hline Low level & $60.54 \%$ & $80.06 \%$ \\
\hline Medium level & $5.80 \%$ & $6.6 \%$ \\
\hline High level & $7.70 \%$ & $8.71 \%$ \\
\hline \multicolumn{3}{|l|}{ Mothers' educational level } \\
\hline Uneducated & $30.09 \%$ & $7.19 \%$ \\
\hline Low level & $62.75 \%$ & 83. $26 \%$ \\
\hline Medium level & $3.88 \%$ & $5.23 \%$ \\
\hline High level & $3.29 \%$ & 4. $33 \%$ \\
\hline \multicolumn{3}{|c|}{$\begin{array}{l}\text { Economic situation of the household dur- } \\
\text { ing the children's adolescence }\end{array}$} \\
\hline Bad & $23.83 \%$ & $13.7 \%$ \\
\hline Intermediate & $20.30 \%$ & $58.41 \%$ \\
\hline Good & $55.87 \%$ & $27.9 \%$ \\
\hline \multicolumn{3}{|l|}{ Gender } \\
\hline Men & $48.73 \%$ & $48.62 \%$ \\
\hline Women & $51.27 \%$ & $51.38 \%$ \\
\hline \multicolumn{3}{|l|}{ Type of contract } \\
\hline Permanent & $65.37 \%$ & $68.90 \%$ \\
\hline Temporal & $34.63 \%$ & $31.10 \%$ \\
\hline \multicolumn{3}{|l|}{ Country of birth } \\
\hline Spain & $94.24 \%$ & $89.89 \%$ \\
\hline Other & $5.76 \%$ & $10.11 \%$ \\
\hline Sample size & 13,080 & 9161 \\
\hline
\end{tabular}

Source: Author's own elaboration

\section{Methodology}

For the measurement of intergenerational mobility, the most commonly used model in the literature is a linear regression of the logarithm of the income or wage of the child based on the father's income or wage. In addition, control variables can be included. The model would therefore be expressed as:

$\log \left(Y_{i}^{t}\right)=\alpha+\beta \log \left(Y_{i}^{t-1}\right)+\varepsilon_{i}^{t}$

in which $Y_{i}^{t}$ is the income of child $\mathrm{i}$ in the current period $t$ and $Y_{i}^{t-1}$ is the income of the father or mother of child $i$ at a previous time $t-1$. The $\beta$ coefficient indicates the inequality that is transmitted between generations, and $(1-\beta)$ is the intergenerational mobility indicator. If $\beta=0$, the parents' income does not influence the children's income and therefore there is complete mobility because the two incomes are independent. If $\beta=1$, the children's income fully depends on the parents' income and there is no income mobility.

In the case of Spain, as we have indicated in previous sections, there are no panel data that link parents' income with their children's income, taking into consideration the total population. We could capture the information about both generations as long as the children belong to the same household as the parents, but this would exclude a large portion of the population of interest. In this paper, we use the economic situation of the household during adolescence and the parents' educational levels as proxy variables for monetary income. Additionally, we include control variables about individual characteristics, such as age, years of experience, or the type of employment contract.

The coefficients of the typical intergenerational mobility models present different problems, as identified by Jäntti and Jenkins (2015). One such problem is that this coefficient reflects income growth as a part of structural mobility. For this reason, we obtain and study the transition matrices between the statuses of parents and children, which capture the probability of intergenerational change in income or other relevant variables, such as educational levels. These matrices provide interesting information on intergenerational income mobility and allow us to obtain an approximation of their description and quantification.

As a descriptive approximation of mobility, we analyse the transition matrices for two different income proxy variables of income: the parents' household economic situation (bad, intermediate, or good) and the educational level of the parents (uneducated, low, medium, and high levels). Additionally, we use the M index or the Prais-Shorrocks index (Prais, 1955; Shorrocks, 1978) to compare the two sets of results. This index is calculated with the number of partitions and with the trace of the transition matrix. The index formula is:

$\mathrm{M}(\mathrm{P})=\frac{\mathrm{n}-\operatorname{tr}(\mathrm{P})}{\mathrm{n}-1}$

in which $\mathrm{n}$ is the number of partitions and $\operatorname{tr}(\mathrm{P})$ is the trace of the transition matrix. The probability of movements regarding the economic situation of the household when the informant was an adolescent is given by the elements outside the main diagonal. When the structure is represented by the identity matrix, there are no transitions between states and, in this case, the index takes its minimum value, which is zero. At the other end, we find the maximum mobility when the rows of the matrix are identical and the probability of transition to any economic situation is independent of the economic situation of the household during adolescence. In this case, the index is one (Shorrocks, 1978). We should note that the index can also take values greater than one when the 
probability of permanence in the same state (located in the trace) is reduced.

Once the transition matrices have been analysed, we conduct a causal study of the influence of the different proxy variables by estimating different econometric models. The model that uses the economic situation of the household as a proxy variable for the parents' income (model 1) is as follows:

$\log \left(Y_{i}^{t}\right)=\beta_{0}+\beta_{1} \operatorname{SitEco1}_{i}^{t-1}+\beta_{2} \operatorname{SitEco3}_{i}^{t-1}+\beta X_{i}^{t}+\varepsilon_{i}^{t}$

The dependent or explained variable, $Y_{i}^{t}$, is the logarithm of the informant's disposable income after taxes and social transfers. The explanatory variables are the following:

- SitEcol: a dummy variable that indicates whether the economic situation in the household during the adult's adolescence was bad.

- SitEco3: a dummy variable that indicates whether the economic situation during the adult's adolescence was good.

Among the control variables $\left(X_{i}^{t}\right)$, we include variables that indicate the following characteristics related to sons and daughters: gender, age and its square, experience and its square, contract type, country of birth and its degree of urbanization, and autonomous community. We also estimate an econometric model that explains the logarithm of the children's income based on the parents' educational levels as independent variables. Although we do not have information on the parents' income, if the postulates of the theory of human capital are fulfilled, a higher level of parental education indicates higher productivity in the labour market and therefore a higher parental income.

The models estimated for the different parental educational levels are expressed as follows:

$\log \left(Y_{i}^{t}\right)=\beta_{0}+\beta_{1} E d u 1_{i}^{t-1}+\beta_{2} E d u 2_{i}^{t-1}+\beta_{3} E d u 3_{i}^{t-1}+\beta X_{i}^{t}+\varepsilon_{i}^{t}$

The dummy variables that indicate the parents' level of education are the following ${ }^{2}$ :

$E d u 1_{i}^{t-1}$ : a dummy variable that indicates a low level (primary education and the first stage of secondary education);

$E d u 2_{i}^{t-1}$ : a dummy variable that indicates a medium level (the second stage of secondary education and training cycles);

$E d u 3_{i}^{t-1}$ : a dummy variable that indicates a high level (university education).

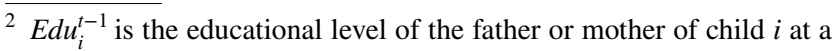
previous time $t-1$.
Table 2 Mobility matrices of the economic situation in 2005

\begin{tabular}{llll}
\hline $\begin{array}{l}\text { Economic situation of } \\
\text { the household during } \\
\text { adolescence }\end{array}$ & \multicolumn{2}{c}{ Current situation of the sons and daughters } \\
\cline { 2 - 4 } & Bad situation & Intermediate & Good situation \\
\hline Bad situation & 41.62 & 51.02 & 7.36 \\
Intermediate & 29.58 & 60.92 & 9.49 \\
Good situation & 17.19 & 64.26 & 18.55 \\
\hline
\end{tabular}

Source: Author's own elaboration from longitudinal LCS dataset

Table 3 Mobility matrices of the economic situation in 2011

\begin{tabular}{llll}
\hline $\begin{array}{l}\text { Economic situation of } \\
\text { the household during } \\
\text { adolescence }\end{array}$ & \multicolumn{2}{l}{ Current situation of the sons and daughters } \\
\cline { 2 - 4 } & Bad situation & Intermediate & Good situation \\
\hline Bad situation & 46.73 & 45.38 & 7.89 \\
Intermediate & 23.31 & 63.47 & 13.22 \\
Good situation & 16.46 & 52.1 & 31.44 \\
\hline
\end{tabular}

Source: Author's own elaboration from longitudinal LCS dataset

We use the level corresponding to people without studies as a reference, which includes all those who have less than primary education. ${ }^{3}$

Firstly, this model is estimated to understand the influence of fathers and mothers separately in two different regressions (models 2 and 3). Secondly, we introduce both together (mothers' and fathers' levels of education) in the same regression (model 4) to determine which influence is more important, that of the father's or the mother's education. Finally, we estimate a fifth model (model 5) including both the economic situation of the household and the parents' educational levels as explanatory variables to ascertain whether the parental education or the parental economic situation mattered the most.

\section{Results}

\section{Mobility Analysis with Transitional Matrices Using the Two Proxy Measures of Parental Wealth}

Tables 2 and 3 present the mobility matrices of the economic situation of parents and children in each of the years considered, 2005 and 2011. In the matrix for 2005, we can observe different facts. First, the most likely state

\footnotetext{
${ }^{3}$ In the 2011 LCS, there is a different aggregation in terms of information on the parents' educational levels from the 2005 LCS. Consequently, we make the data of the two years consistent so that they can be compared.
} 
Table 4 Mobility matrix of father-child educational levels in 2005

\begin{tabular}{llllc}
\hline Father's level of study & \multicolumn{4}{l}{ Child's level of study } \\
\cline { 2 - 5 } & Uneducated & Low level & Medium level & High level \\
\hline Uneducated & 7.55 & 71.69 & 12.39 & 8.37 \\
Low level & 0.51 & 50.75 & 22.79 & 25.95 \\
Medium level & 0.12 & 14.28 & 34.38 & 51.22 \\
High level & 0.13 & 6.60 & 21.12 & 72.16 \\
\hline
\end{tabular}

Source: Author's own elaboration from longitudinal LCS dataset

\begin{tabular}{llllc}
\hline Mother's level of study & \multicolumn{4}{l}{ Child's level of study } \\
\cline { 2 - 5 } & Uneducated & Low level & Medium level & High level \\
\hline Uneducated & 6.80 & 71.05 & 12.67 & 9.48 \\
Low level & 0.37 & 45.98 & 23.99 & 29.66 \\
Medium level & 0.13 & 6.59 & 32.75 & 60.53 \\
High level & 0.04 & 4.97 & 21.19 & 73.79 \\
\hline
\end{tabular}

Source: Author's own elaboration from longitudinal LCS dataset.
Table 5 Mobility matrix of mother-child educational levels in 2005
Table 6 Mobility matrix of father-child educational levels in 2011

of arrival, independent of the economic situation of the household during adolescence, is an intermediate economic situation. Likewise, we can conclude that, in 2005, there was intergenerational mobility and that it manifested itself in both ascending and descending patterns. Thus, it is found that those who were in a bad economic situation in their adolescence are less likely to improve than to worsen their situation than those who were in a good situation. The 2011 matrix shows a similar situation, although some changes should be highlighted. Thus, an increase in the probability of maintaining their status can be observed for those who were in a household with a good situation (ranging from 18.55 to $31.44 \%$ ) and, in general terms, when simply analysing the diagonal of the matrix, we observe that, in 2011, there is less mobility, which limits the chances of improvement for those who had a poor economic situation in their adolescence. Thus, comparing the two years, we can see that, with the arrival of the crisis, the ascending mobility of those who had a bad economic situation during their adolescence is reduced, the descending mobility of those who had a good economic situation is reduced, and the intermediate group maintains and even improves its situation. The result is a reduction in mobility, increasing the influence of the type of household during adolescence on income, with the household type playing a hindering role in the capacity of advancement for those who came from underprivileged homes, as highlighted by Ayala (2016).

Additionally, to aggregate the information in a synthetic mobility indicator, we calculate Shorrocks's M index, which takes values of 0.895 for 2005 and 0.792 for 2011 . The index values are close to 1 , thus expounding the existence of high levels of mobility in both years, but it also indicates a clear

\begin{tabular}{lllll}
$\begin{array}{l}\text { Table } 6 \\
\text { Father's level of } \\
\text { study }\end{array}$ & \multicolumn{4}{l}{ Child's level of study } \\
\cline { 2 - 5 } & Uneducated & Low level & Medium level & High level \\
\hline Uneducated & 16.05 & 69.23 & 8.95 & 5.78 \\
Low level & 1.68 & 48.08 & 23.5 & 26.73 \\
Medium level & 0.65 & 16.03 & 28.88 & 54.44 \\
High level & 0.40 & 6.23 & 21.13 & 72.24 \\
\hline
\end{tabular}

Source: Author's own elaboration from longitudinal LCS dataset

decrease in 2011, in line with the facts previously detected in the structure of the transition matrix.

The transition matrices presented in Tables 4, 5, 6, and 7 show the probability of transition of the educational levels of parents and their sons or daughters. From these results, we can conclude that, in 2005, transitions between all states were feasible, although with very low probabilities of sons and daughters remaining at the level of no education that their parents had or descending to it from other levels. This conclusion reflects the implementation of policies of generalization and improvement of education carried out since the transition to democracy. This positive effect is also manifested in the existence of higher probabilities above the main diagonal, which indicates a very clear predominance of upward mobility patterns. Finally, it should be noted that the children of parents with high educational levels are the ones with the greatest stability at this level, with probabilities greater than $70 \%$. With regard to mothers, we note that, although there is more mobility, the chances of transition are similar with the exception of the probability of reaching a high educational level from a medium level, which is nine percentage points higher than in the case of 
Table 7 Mobility matrix of mother-child educational levels in 2011

\begin{tabular}{llllc}
\hline Mother's level of study & \multicolumn{4}{l}{ Child's level of study } \\
\cline { 2 - 5 } & Uneducated & Low level & Medium level & High level \\
\hline Uneducated & 12.95 & 74.40 & 8.63 & 4.02 \\
Low level & 1.42 & 44.56 & 24.28 & 29.74 \\
Medium level & 0.79 & 11.74 & 26.04 & 61.43 \\
High level & 0.12 & 6.09 & 17.94 & 75.85 \\
\hline
\end{tabular}

Source: Author's own elaboration from longitudinal LCS dataset parents, indicating greater ascending mobility. It also highlights lower descending mobility by reducing the likelihood that sons and daughters will reach lower levels than their mothers.

Similar mobility patterns are also detected in the matrix of educational levels in 2011, but children of parents without education have a greater chance of staying at the same level, double that found in the 2005 matrices. Therefore, the group of children of uneducated parents-the most disadvantaged - has reduced its upward mobility in 2011. The probability of reaching a high level is higher in relation to mothers' education than in the case of fathers, similar to the data from 2005.

To synthesize the information, we obtain the $\mathrm{M}$ index, presented in Table 8 . The values of the index indicate a slight reduction, which points to a stabilization of the value if we a perform a hypothesis test on the evolution of the values presented in Table 7. However, considering that the index indicates maximum mobility when its value is one and that there is no mobility when its value is zero, we can say that, in both years, there is high educational mobility. On the other hand, it highlights the fact that there is more mobility with respect to the educational level of mothers than with respect to parents. Such mobility-as we have seen when analysing the elements of the transition matrix-is primarily upwards.

Therefore, in both years analysed, high mobility can be detected both in the matrices of the economic situation of the household and in those of the educational levels of fathers and mothers. However, the reduction in mobility in the matrix of transitions of the economic situation is clear, while mobility in educational levels is basically maintained. Educational levels are not direct indicators of income, and their changes are due to longer-term processes in which the variations are less perceptible and are safeguarded by a public education system.

\section{Mobility Analysis Using Econometric Models}

Tables 9 and 10 show the estimates of the coefficients of greatest interest for the conclusions on mobility in the five estimated models. To complete this information, the annex presents in detail the estimates of all the explanatory variables included as well as the relevant goodness-of-fit measures.

As indicated in the methodology section, the use of the coefficients of econometric models for the study of mobility presents different problems. Thus, according to McMurrer et al. (1997), economic growth can generate mobility simply by producing improvements in productivity and income, which make it seem that children are better off than their parents when, however, the improvements are general. On the other hand, the use of income proxy variables instead of monetary income itself is not without biases as they can also induce an overvaluation of the influence of economic achievements in the next generation (Jenkins \& Siedler, 2007). Therefore, instead of focusing on a longitudinal comparison of the coefficients, the analysis and interpretation of the results in this section will focus on assessing the influence of the different factors in each of the years of study to avoid the effects of economic growth over time that distort the estimates of the coefficients of the proxy variables.

The results of model 1, which links the income of an individual to the situation of his or her household in adolescence for the years 2005 and 2011, reveal that the coefficients of the variables that connect the income of the child to the income of the father through the household's economic situation, when the adult was an adolescent, are all significant. Taking as a reference the category of having had an intermediate economic situation, we observe that, in 2005, the logarithm of the income of an individual is $17.76 \%$ lower when there was a bad economic situation in the home during adolescence. If we compare it with a good situation, the logarithm of incomes is $20.66 \%$ higher than that of those individuals residing in a household with an intermediate

Table 8 Shorrocks's M index for educational mobility: 2005 and 2011

\begin{tabular}{lll}
\hline M index & Educational level of fathers & $\begin{array}{l}\text { Educational } \\
\text { level of moth- } \\
\text { ers }\end{array}$ \\
\hline 2005 & 0.78387 & 0.80227 \\
2011 & 0.78250 & 0.80200 \\
\hline
\end{tabular}

Source: Author's own elaboration from longitudinal LCS dataset 
Table 9 Coefficients of the proxy variables in the 2005 models

\begin{tabular}{|c|c|c|c|c|c|}
\hline & Model 1 & Model 2 & Model 3 & Model 4 & Model 5 \\
\hline Low educational level of the fathers & - & $\begin{array}{l}0.451 * * * \\
(0.062)\end{array}$ & - & $\begin{array}{l}0.24 * * \\
(0.836)\end{array}$ & $\begin{array}{l}0.219 * * \\
(0.085)\end{array}$ \\
\hline Medium educational level of the fathers & - & $\begin{array}{l}0.802 * * * \\
(0.106)\end{array}$ & - & $\begin{array}{l}0.497 * * * \\
(0.123)\end{array}$ & $\begin{array}{l}0.456 * * * \\
(0.124)\end{array}$ \\
\hline High educational level of the fathers & - & $\begin{array}{l}1.219 * * * \\
(0.096)\end{array}$ & - & $\begin{array}{l}0.871 \text { *** } \\
(0.12)\end{array}$ & $\begin{array}{l}0.825^{* * * *} \\
(0.121)\end{array}$ \\
\hline Low educational level of the mothers & - & - & $\begin{array}{l}0.505 * * * \\
(0.058)\end{array}$ & $\begin{array}{l}0.326 * * * \\
(0.081)\end{array}$ & $\begin{array}{l}0.309 * * * \\
(0.081)\end{array}$ \\
\hline Medium educational level of the mothers & - & - & $\begin{array}{l}1.095^{* * * *} \\
(0.123)\end{array}$ & $\begin{array}{l}0.665^{* * * *} \\
(0.140)\end{array}$ & $\begin{array}{l}0.640 * * * \\
(0.142)\end{array}$ \\
\hline High educational level of the mothers & - & - & $\begin{array}{l}1.167 * * * \\
(0.131)\end{array}$ & $\begin{array}{l}0.606 * * * \\
(0.154)\end{array}$ & $\begin{array}{l}0.585^{* * * *} \\
(0.156)\end{array}$ \\
\hline Bad economic situation & $\begin{array}{l}-0.178^{*} \\
(0.073)\end{array}$ & - & - & - & $\begin{array}{l}-0.090 \\
(0.076)\end{array}$ \\
\hline Good economic situation & $\begin{array}{l}0.207 * * * \\
(0.061)\end{array}$ & - & - & - & $\begin{array}{l}0.118 \\
(0.063)\end{array}$ \\
\hline Sample size & 13,840 & 13,243 & 13,626 & 13,080 & 12,883 \\
\hline $\mathrm{F}$ & 177.92 & 169.00 & 173.27 & 152.17 & 141.46 \\
\hline Prob $>F$ & 0.000 & 0.000 & 0.000 & 0.000 & 0.000 \\
\hline $\mathrm{R}^{2}$ & 0.353 & 0.362 & 0.36 & 0.364 & 0.363 \\
\hline
\end{tabular}

${ }^{*} \mathrm{p}<0.05 . * * \mathrm{p}<0.01 . * * * \mathrm{p}<0.001$.

Source: Author's own elaboration from longitudinal LCS dataset

Table 10 Coefficients of the proxy variables in the 2011 models

\begin{tabular}{|c|c|c|c|c|c|}
\hline & Model 1 & Model 2 & Model 3 & Model 4 & Model 5 \\
\hline Low educational level of the fathers & - & $\begin{array}{l}0.35 * * * \\
(0.045)\end{array}$ & - & $\begin{array}{l}0.158 * * * \\
(0.056)\end{array}$ & $\begin{array}{l}0.129 * * \\
(0.055)\end{array}$ \\
\hline Medium educational level of the fathers & - & $\begin{array}{l}0.556 * * * \\
(0.050)\end{array}$ & - & $\begin{array}{l}0.349 * * * \\
(0.061)\end{array}$ & $\begin{array}{l}0.309 * * * \\
(0.060)\end{array}$ \\
\hline High educational level of the fathers & - & $\begin{array}{l}0.649 * * * \\
(0.05)\end{array}$ & - & $\begin{array}{l}0.415 * * * \\
(0.061)\end{array}$ & $\begin{array}{l}0.359 * * * \\
(0.061)\end{array}$ \\
\hline Low educational level of the mothers & - & - & $\begin{array}{l}0.369 * * * \\
(0.036)\end{array}$ & $\begin{array}{l}0.281 * * * \\
(0.044)\end{array}$ & $\begin{array}{l}0.259 * * * \\
(0.044)\end{array}$ \\
\hline Medium educational level of the mothers & - & - & $\begin{array}{l}0.512 * * * \\
(0.047)\end{array}$ & $\begin{array}{l}0.307 * * * \\
(0.055)\end{array}$ & $\begin{array}{l}0.283 * * * \\
(0.056)\end{array}$ \\
\hline High educational level of the mothers & - & - & $\begin{array}{l}0.627 * * * \\
(0.049)\end{array}$ & $\begin{array}{l}0.387 * * * \\
(0.058)\end{array}$ & $\begin{array}{l}0.343 * * * \\
(0.059)\end{array}$ \\
\hline Bad situation & $\begin{array}{l}-0.182 * * * \\
(0.025)\end{array}$ & - & - & - & $\begin{array}{l}-0.134 * * * \\
(0.025)\end{array}$ \\
\hline Good situation & $\begin{array}{l}0.107 * * * \\
(0.015)\end{array}$ & - & - & - & $\begin{array}{l}0.072 \text { *** } \\
(0.016)\end{array}$ \\
\hline Sample size & 8936 & 9165 & 9192 & 9161 & 8897 \\
\hline $\mathrm{F}$ & 90.12 & 93.74 & 91.49 & 86.98 & 91.70 \\
\hline Prob $>F$ & 0.000 & 0.000 & 0.000 & 0.000 & 0.000 \\
\hline $\mathrm{R}^{2}$ & 0.281 & 0.3 & 0.29 & 0.302 & 0.304 \\
\hline
\end{tabular}

economic situation. Therefore, the above results demonstrate that the economic situation during adolescence is influential in determining the income earned by sons and daughters. In any case, the absolute values of the coefficients do not indicate a totally decisive weight of the family origin, leaving an opportunity for mobility.

In 2011, the logarithm of the income with a bad economic situation is $18.12 \%$ lower than the reference variable. If the respondents had a good economic situation, the 
logarithm of their income will be $10.73 \%$ higher than if they had an intermediate economic situation. Both coefficients are statistically significant, indicating their decisive influence on the dependent variable.

In conclusion, we can say that the results of model 1 indicate that, in both years, there is an influence of the household's economic situation during adolescence on the income of the children, although the magnitude of the coefficients allows the existence of intergenerational mobility in both years to be considered, both before and during the economic crisis.

In the results of model 2, we can observe that the coefficients of the variables that relate the child's income to that of the father through educational levels are positive and statistically significant. The reference category for dummy variables of educational levels is the state of being uneducated; therefore, as expected, if the educational level is higher, the coefficient is higher. With respect to the coefficients' values, we observe that, in 2005, with a low level of studies, the value of the dependent variable is $45 \%$ higher than it would have been without education (these percentages being $80.19 \%$ and $121.9 \%$ for the levels of medium and high education, respectively).

In the case of mothers' levels of education (model 3 ), the coefficients are higher than those obtained in the fathers' estimates except for the high level of education. All these coefficients (models 2 and 3 ) tell us that, despite the existence of mobility, there is a significant influence of the educational levels of parents on their children's income. In 2011, most explanatory variables have significant coefficients. Focusing on the relevant variables for the mobility analysis, we observe that the coefficients of different educational levels, as in 2005 , are positive and increasing, indicating higher income as the level of education increases. In any case, it is intuitive that, in 2011, the influence of the educational level of the parents takes on greater relevance than that of the mothers, not only for the higher educational level. Therefore, we can conclude that there is mobility with respect to the educational levels of parents and that the influence of these levels on children's income is significant in both years.

To compare the influence of the education of fathers and mothers in the same model, once the absence of multicollinearity between the two variables has been verified, a regression, which includes the levels of education of fathers and mothers simultaneously as explanatory variables (model 4), was performed. The estimates of this model, for 2005 and 2011, show that the coefficients of the variables relating to parental education are all statistically significant, indicating similar conclusions to those detected in the models that considered the educational levels of fathers and mothers separately. We can point out that the coefficient values for the fathers' educational level in 2011 are slightly higher than those for the mother's educational level except for the low educational level.

Finally, we consider the results of model 5, which incorporates the indicator of the economic situation of the household and the educational level of the parents as a proxy variable for income and education. We observe that the coefficients of the educational variables in 2005 are significant. However, those of the economic situation are not statistically significant except for the variable corresponding to the good economic situation, which is significant at the $10 \%$ level. In 2011, all the explanatory variables used as a proxy for parental income are statistically significant and, regarding the economic situation, we perceive that the coefficient relative to a good economic situation is very low. Thus, it can be concluded that the educational level of the parents has a greater influence on the income of the children than the economic situation and, furthermore, that the educational level of the fathers has a greater influence than that of the mothers in 2011.

\section{Conclusions}

The main objective of this paper is to provide an approximation of the situation of intergenerational mobility of income in Spain in two years situated in very different phases of the economic cycle: 2005 and 2011. To this end, we use two parental income proxy variables: the economic situation of the parents' home in the children's adolescence and the educational levels of the parents. The results obtained in the transition matrices and the estimates of the econometric models allow us to draw conclusions on the intergenerational mobility of income in Spain in the years considered.

On the one hand, the analysis of the transition matrices of the economic situation of parents and children and of their $M$ index values shows the existence of mobility in Spain in 2005 and 2011, although a reduction is observed in 2011. On the other hand, educational mobility is maintained between the two years, showing that this proxy variable is less subject to the ups and downs of the economic cycle and that the changes respond to structural factors inherent to a more consolidated educational system.

Regarding the analysis of econometric models, they allow us to conclude that there is a significant influence of family origin on the income of the children that is compatible with the existence of mobility between different statuses. There is also a greater influence on the income of the children of the parents' educational levels than of the economic situation of the home during the adolescence of the sons and daughters.

In general, our conclusions are in line with those of Barcena and Moro (2013), Celorrio (2013), and Cueto (2015), who pointed out the effects of the economic crisis and public spending adjustment policies as possible factors that are 
responsible for the reduction of mobility. Therefore, policies aimed at reducing inequality and poverty, as well as any measures that promote equal opportunities, must be strengthened to reverse the trend of reduced mobility.

Our approach is not free from limitations. These are especially related to the data sources since the impossibility of having parents' and children's income in the same samples makes it necessary to use proxy variables with broad classification categories. This drawback does not allow an accurate analysis based on continuous and direct income indicators. This problem is coupled with the biases introduced in the coefficients of the econometric models, which reflect not only mobility but also the effects of economic growth.
Regarding directions for further research, we can extend the research on intergenerational mobility along several lines. This approach could be used to examine the scope and determinants of intergenerational mobility by performing a comparative international analysis using harmonised information, which is currently available in certain regional contexts, such as Europe.

\section{Appendix}

See Tables 11, 12, 13, 14, and 15. 
Table 11 Estimates of intergenerational mobility

\begin{tabular}{|c|c|c|c|}
\hline Country & Article & Model & Variables \\
\hline US & $\begin{array}{l}\text { Behrman and } \\
\text { Taubman } \\
\text { (1990) }\end{array}$ & $\begin{array}{l}\text { OLS } \\
\ln Y_{t}^{\text {child }}=\beta_{0}+\beta_{1} Y_{t}^{\text {father }}+\varepsilon_{t}^{\text {child }}\end{array}$ & $\begin{array}{l}\text { Explained: logarithm of the child's earnings } \\
\text { Explanatory: logarithm of father's earnings } \\
\text { For different ages of the child: } 15 \text { years, } 16 \text { years and period 1975-1984 }\end{array}$ \\
\hline US & Solon (1992) & $\begin{array}{l}\text { OLS } \\
\mathrm{Y}_{1 \mathrm{it}}=\left(\alpha_{1}-\rho \alpha_{0}\right)+\rho \mathrm{y}_{0 \mathrm{is}}+\beta_{1} \mathrm{~A}_{1 \mathrm{it}}+\gamma_{1} \mathrm{~A}_{1 \mathrm{it}}^{2} \\
\quad-\rho \beta_{0} \mathrm{~A}_{0 \mathrm{is}}-\rho \gamma \mathrm{A}_{\text {ois }}^{2}+\varepsilon_{\mathrm{i}}+v_{1 \mathrm{it}}-\rho \mathrm{v}_{0 \mathrm{is}}\end{array}$ & $\begin{array}{l}\text { Explained: log-run economic status of the son (permanent annual earn- } \\
\text { ings of the son) } \\
\text { Explanatory: log-run economic status of the father (permanent annual } \\
\text { earnings of the father) }\left(\mathrm{y}_{0 \mathrm{is}}\right) \text {, age of the son in year } \mathrm{t}\left(\mathrm{A}_{1 \mathrm{it}}\right) \text {, quadratic } \\
\text { form of the son's age in year } \mathrm{t}\left(\mathrm{A}_{1 \mathrm{it}}^{2}\right) \text {, father age in year } \mathrm{t}\left(\mathrm{A}_{0 \mathrm{it}}\right) \text {, quad- } \\
\text { ratic form of the father's age in year } \mathrm{t}\left(\mathrm{A}^{2}{ }_{0 \mathrm{it}}\right) \text {, transitory fluctuation of } \\
\text { the son }\left(\mathrm{v}_{1 \mathrm{is})} \text { and transitory fluctuation of the father }\left(\mathrm{v}_{0 \mathrm{is}}\right)\right.\end{array}$ \\
\hline US & $\begin{array}{l}\text { Zimmerman } \\
(1992)\end{array}$ & $\begin{array}{l}\mathrm{OLS} \\
Y_{\mathrm{i}}^{\text {son }}=\alpha+\beta \mathrm{Y}_{\mathrm{i}}^{\text {father }}+\varepsilon_{\mathrm{i}}^{\text {son }} \\
\mathrm{IV} \\
Y_{\mathrm{i}}^{\text {son }}=\alpha+\beta \mathrm{Y}_{\mathrm{i}}^{\text {father }}+\delta \mathrm{D}_{\mathrm{i}}^{\text {father }}+\varepsilon_{\mathrm{i}}^{\text {son }}\end{array}$ & $\begin{array}{l}\text { Explained: permanent status of the child } \\
\text { Explanatory: permanent status of the father } \\
\text { Explained: permanent status of the child } \\
\text { Explanatory: permanent status of the father and an average of the value of } \\
\text { Duncan's index }\left(\mathrm{D}_{\mathrm{i}}^{\text {father }}\right) \text { as an instrument }\end{array}$ \\
\hline Malaysia & $\begin{array}{l}\text { Lillard and } \\
\text { Kilburn } \\
(1995)\end{array}$ & $\begin{array}{l}\text { OLS } \\
Y_{c}=\beta_{0}+\beta_{1} Y_{f}+\beta_{2}{ }^{\prime} X_{c}+\delta_{f}+\eta_{c}\end{array}$ & $\begin{array}{l}\text { Explained: age-adjusted child's log permanent earnings }\left(\mathrm{Y}_{\mathrm{c}}\right) \\
\text { Explanatory: age-adjusted log permanent earnings of the father }\left(\mathrm{Y}_{\mathrm{f}}\right) \text {, } \\
\text { family characteristics }\left(\mathrm{X}_{\mathrm{c}}\right) \text {, endowments }\left(\delta_{\mathrm{f}}\right) \text { y permanent earing of the } \\
\text { child }\left(\eta_{\mathrm{c}}\right)\end{array}$ \\
\hline Britain & $\begin{array}{l}\text { Dearden et al. } \\
\text { (1997) }\end{array}$ & $\begin{array}{l}\text { IV } \\
\hat{y}_{r i}^{\text {child }}=\alpha+\beta \hat{y}_{r i}^{\text {parent }}+\varepsilon_{\mathrm{i}} \\
\text { Con } \hat{Y}_{\mathrm{ri}}=\mathrm{y}_{\mathrm{it}}-\hat{\gamma} \mathrm{x}_{\mathrm{it}}=\delta \mathrm{q}_{\mathrm{i}}+\mathrm{f}_{\mathrm{i}}+\gamma \mathrm{x}_{\mathrm{it}}+\mathrm{w}_{\mathrm{it}}= \\
=\mathrm{y}_{\mathrm{i}}+\mathrm{w}_{\mathrm{it}} \\
\hat{y}_{p i}^{\text {child }}=\alpha+\beta \hat{y}_{p i}^{\text {parent }}+\varepsilon_{\mathrm{i}} \\
\text { Con } \hat{y}_{p i}^{\text {child }}=\hat{\delta} \mathrm{q}_{\mathrm{i}}=\mathrm{y}_{\mathrm{i}}-\mathrm{f}_{\mathrm{i}}\end{array}$ & $\begin{array}{l}\text { Explained: measure of the permanent status of the child (permanent } \\
\text { income) } \\
\text { Explanatory: measure of the permanent status of the father (permanent } \\
\text { income) } \\
\text { Instrument explanatory: } \\
\text { Case 1: Permanent income and vector with characteristics which affect to } \\
\text { current income (x) } \\
\text { Case 2: vector with characteristics which affect to permanent income (q) }\end{array}$ \\
\hline Canada & $\begin{array}{l}\text { Fortin and } \\
\text { Lefebvre } \\
(1998)\end{array}$ & $\begin{array}{l}\mathrm{IV} \\
\mathrm{Y}_{\mathrm{i}}^{\text {child }}=\beta_{0}+\beta_{1} \mathrm{y}_{\mathrm{i}}^{\text {parent }}+\varepsilon_{\mathrm{i}} \\
\mathrm{Y}_{\mathrm{i}}^{\text {parent }}=\mathrm{k}_{\mathrm{t}} \text { Occ }_{\mathrm{kt}}{ }^{\text {parent }}+\mathrm{v}_{\mathrm{it}}{ }^{\text {parent }}\end{array}$ & $\begin{array}{l}\text { Explained: income of the child }\left(\mathrm{Y}_{\mathrm{i}}^{\text {child }}\right) \\
\text { Explanatory: income of the father }\left(\mathrm{y}_{\mathrm{i}}^{\text {parent }}\right) \\
\text { estimated average income for occupation } \mathrm{k} \text { in year } \mathrm{t}\left(\mathrm{k}_{\mathrm{t}}\right) \text { y dummy vari- } \\
\left.\quad \text { ables indicating occupation } \mathrm{k} \text { of the father (Occ }{ }^{\text {parent }}\right)\end{array}$ \\
\hline Canada & $\begin{array}{l}\text { Corak and } \\
\text { Heisz } \\
(1999)\end{array}$ & $\begin{array}{l}\text { OLS } \\
\mathrm{Y}_{\mathrm{i}}(\mathrm{t})=\beta_{0}+\beta_{1} \bar{Y}_{i}(\mathrm{t}-1)+\beta_{2} \text { AgeSon }+\beta_{3} \\
\quad \text { AgeSon }{ }^{2}+\beta_{2} \text { AgeFather }+\beta_{3} \\
\text { AgeFather }{ }^{2}+\varepsilon_{\mathrm{i}}\end{array}$ & $\begin{array}{l}\text { Explained: log of permanent children, } s \text { income (annual income) } \\
\text { Explanatory: log of the average annual income of several years }\left(\bar{Y}_{i}\right) \text {, } \\
\text { age of the child, quadratic form of the son's age, quadratic form of the } \\
\text { father's age }\end{array}$ \\
\hline Sweden & $\begin{array}{l}\text { Österberg } \\
(2000)\end{array}$ & $\begin{array}{l}\text { OLS } \\
Y_{i, c}=\beta Y_{i, p}+\varepsilon_{i}\end{array}$ & $\begin{array}{l}\text { Explained: child's log of permanent income of } 3 \text { years } \\
\text { Explanatory: father's log of permanent income of } 3 \text { years }\end{array}$ \\
\hline $\begin{array}{l}\text { South } \\
\text { Africa }\end{array}$ & Hertz (2001) & $\begin{array}{l}\text { OLS } \\
y_{i}=\beta_{1} y_{i}^{\prime}+\beta_{2} S_{i}^{\prime}+\beta_{3} S_{i}+e_{i}\end{array}$ & $\begin{array}{l}\text { Explained: child's lifetime earnings } \\
\text { Explanatory: parental earnings, parental education y child education }\end{array}$ \\
\hline
\end{tabular}

Source: Author's own elaboration 
Table 12 Estimation of the income logarithm with the economic situation

\begin{tabular}{|c|c|c|}
\hline & 2005 & 2011 \\
\hline Bad situation & $\begin{array}{l}-0.178^{*} \\
(0.073)\end{array}$ & $\begin{array}{l}-0.182 * * * \\
(0.025)\end{array}$ \\
\hline Good situation & $\begin{array}{l}0.207 * * * \\
(0.061)\end{array}$ & $\begin{array}{l}0.107 * * * \\
(0.015)\end{array}$ \\
\hline Gender & $\begin{array}{l}-1.054 * * * \\
(0.048)\end{array}$ & $\begin{array}{l}-0.236^{* * *} \\
(0.014)\end{array}$ \\
\hline Age & $\begin{array}{l}-0.444 * * * \\
(0.025)\end{array}$ & $\begin{array}{l}-0.021^{* *} \\
(0.01)\end{array}$ \\
\hline Age2 & $\begin{array}{l}0.003 * * * \\
(0.000)\end{array}$ & $\begin{array}{l}0.000 * * \\
(0.000)\end{array}$ \\
\hline Type of contract & $\begin{array}{l}1.185^{* * * *} \\
(0.061)\end{array}$ & $\begin{array}{l}0.629 * * * \\
(0.021)\end{array}$ \\
\hline Country of birth & $\begin{array}{l}0.040 \\
(0.112)\end{array}$ & $\begin{array}{l}0.192 * * * \\
(0.026)\end{array}$ \\
\hline Experience & $\begin{array}{l}0.313 * * * \\
(0.010)\end{array}$ & $\begin{array}{l}0.037 * * * \\
(0.004)\end{array}$ \\
\hline Experience2 & $\begin{array}{l}-0.004 * * * \\
(0.000)\end{array}$ & $\begin{array}{l}-0.001^{* * *} \\
(0.000)\end{array}$ \\
\hline Half populated & $\begin{array}{l}-0.117^{\dagger} \\
(0.065)\end{array}$ & $\begin{array}{l}-0.061 * * * \\
(0.02)\end{array}$ \\
\hline Low populated & $\begin{array}{l}-0.176^{* *} \\
(0.062)\end{array}$ & $\begin{array}{l}-0.166^{* * *} \\
(0.019)\end{array}$ \\
\hline Galicia & $\begin{array}{l}0.142 \\
(0.123)\end{array}$ & $\begin{array}{l}-0.120^{* * *} \\
(0.036)\end{array}$ \\
\hline Asturias & $\begin{array}{l}0.074 \\
(0.143)\end{array}$ & $\begin{array}{l}-0.098^{* *} \\
(0.036)\end{array}$ \\
\hline Cantabria & $\begin{array}{l}0.002 \\
(0.173)\end{array}$ & $\begin{array}{l}-0.211^{* * *} \\
(0.048)\end{array}$ \\
\hline País Vasco & $\begin{array}{l}0.142 \\
(0.130)\end{array}$ & $\begin{array}{l}-0.000 * * * \\
(0.036)\end{array}$ \\
\hline Navarra & $\begin{array}{l}0.108 \\
(0.144)\end{array}$ & $\begin{array}{l}0.071 * \\
(0.037)\end{array}$ \\
\hline La Rioja & $\begin{array}{l}-0.281^{\dagger} \\
(0.154)\end{array}$ & $\begin{array}{l}-0.137 * * * \\
(0.043)\end{array}$ \\
\hline \multirow[t]{2}{*}{ Aragon } & $\begin{array}{l}-0.047 \\
(0.134)\end{array}$ & $\begin{array}{l}-0.101^{* * *} \\
(0.036)\end{array}$ \\
\hline & 2005 & 2011 \\
\hline Castilla y León & $\begin{array}{l}0.059 \\
(0.128)\end{array}$ & $\begin{array}{l}-0.090 * * * \\
(0.032)\end{array}$ \\
\hline Castilla La Mancha & $\begin{array}{l}-0.140 \\
(0.137)\end{array}$ & $\begin{array}{l}-0.094 * * * \\
(0.040)\end{array}$ \\
\hline Extremadura & $\begin{array}{l}0.228 \\
(0.153)\end{array}$ & $\begin{array}{l}-0.151^{* * *} \\
(0.047)\end{array}$ \\
\hline Cataluña & $\begin{array}{l}-0.092 \\
(0.107)\end{array}$ & $\begin{array}{l}-0.071^{* * *} \\
(0.025)\end{array}$ \\
\hline Com. Valenciana & $\begin{array}{l}-0.396^{* * *} \\
(0.116)\end{array}$ & $\begin{array}{l}-0.210^{* * *} \\
(0.030)\end{array}$ \\
\hline Islas Baleares & $\begin{array}{l}0.129 \\
(0.142)\end{array}$ & $\begin{array}{l}-0.108^{* * *} \\
(0.04)\end{array}$ \\
\hline Andalucía & $\begin{array}{l}-0.122 \\
(0.112)\end{array}$ & $\begin{array}{l}-0.283^{* * *} \\
(0.034)\end{array}$ \\
\hline Murcia & $\begin{array}{l}-0.387^{*} \\
(0.143)\end{array}$ & $\begin{array}{l}-0.149 * * * \\
(0.04)\end{array}$ \\
\hline
\end{tabular}


Table 12 (continued)

\begin{tabular}{lll}
\hline & 2005 & 2011 \\
\hline Canarias & 0.188 & $-0.213^{* * *}$ \\
Sample size & $(0.131)$ & $(0.041)$ \\
F & 13,840 & 8936 \\
Prob $>$ F & 177.92 & 90.12 \\
$\mathrm{R}^{2}$ & 0.000 & 0.000 \\
\hline
\end{tabular}

(1) Dummy of economic situation: 1 =bad economic situation, $2=$ intermediate economic situation, $3=$ good economic situation. (2) Dummy of gender: $0=$ man; $1=$ women. (3) Dummy of type of contract: $0=$ temporal contract, $1=$ permanent contract. (4) Dummy of country of birth: $0=$ no Spain, $1=$ Spain. (5) Dummy of urbanization: $1=$ high populated, $2=$ half populated, $3=$ low populated. (6) Dummy of regions

${ }^{\dagger} \mathrm{p}<0.1 . * \mathrm{p}<0.05$. $* * \mathrm{p}<0.01 . * * * \mathrm{p}<0.001$

Source: Author's own elaboration from longitudinal LCS dataset

Table 13 Estimation of the income logarithm with the educational levels

\begin{tabular}{|c|c|c|c|c|}
\hline & \multicolumn{2}{|l|}{2005} & \multicolumn{2}{|l|}{2011} \\
\hline & Fathers & Mothers & Fathers & Mothers \\
\hline Low educational level & $\begin{array}{l}0.451 * * * \\
(0.062)\end{array}$ & $\begin{array}{l}0.505 * * * \\
(0.058)\end{array}$ & $\begin{array}{l}0.35^{* * *} \\
(0.045)\end{array}$ & $\begin{array}{l}0.369 * * * \\
(0.036)\end{array}$ \\
\hline Medium educational level & $\begin{array}{l}0.802 * * * \\
(0.106)\end{array}$ & $\begin{array}{l}1.095 * * * \\
(0.123)\end{array}$ & $\begin{array}{l}0.556^{* * * *} \\
(0.050)\end{array}$ & $\begin{array}{l}0.512 * * * \\
(0.047)\end{array}$ \\
\hline High educational level & $\begin{array}{l}1.219 * * * \\
(0.096)\end{array}$ & $\begin{array}{l}1.167 * * * \\
(0.131)\end{array}$ & $\begin{array}{l}0.649 * * * \\
(0.05)\end{array}$ & $\begin{array}{l}0.627 * * * \\
(0.049)\end{array}$ \\
\hline Gender & $\begin{array}{l}-1.058^{* * * *} \\
(0.049)\end{array}$ & $\begin{array}{l}-1.068^{* * * *} \\
(0.048)\end{array}$ & $\begin{array}{l}-0.243 * * * \\
(0.014)\end{array}$ & $\begin{array}{l}-0.244^{* * * *} \\
(0.014)\end{array}$ \\
\hline Age & $\begin{array}{l}-0.438 * * * \\
(0.026)\end{array}$ & $\begin{array}{l}-0.421 * * * \\
(0.025)\end{array}$ & $\begin{array}{l}-0.019 * * \\
(0.01)\end{array}$ & $\begin{array}{l}-0.019 * * \\
(0.01)\end{array}$ \\
\hline Age2 & $\begin{array}{l}0.003 * * * \\
(0.000)\end{array}$ & $\begin{array}{l}0.003 * * * \\
(0.000)\end{array}$ & $\begin{array}{l}0.000 * * \\
(0.000)\end{array}$ & $\begin{array}{l}0.000 * * \\
(0.000)\end{array}$ \\
\hline Type of contract & $\begin{array}{l}1.138 * * * \\
(0.062)\end{array}$ & $\begin{array}{l}1.173 * * * \\
(0.061)\end{array}$ & $\begin{array}{l}0.622 * * * \\
(0.021)\end{array}$ & $\begin{array}{l}0.623 * * * \\
(0.021)\end{array}$ \\
\hline Country of birth & $\begin{array}{l}0.176 \\
(0.117)\end{array}$ & $\begin{array}{l}0.175 \\
(0.114)\end{array}$ & $\begin{array}{l}0.209 * * * \\
(0.025)\end{array}$ & $\begin{array}{l}0.207 * * * \\
(0.025)\end{array}$ \\
\hline Experience & $\begin{array}{l}0.322 * * * \\
(0.322)\end{array}$ & $\begin{array}{l}0.317 * * * \\
(0.010)\end{array}$ & $\begin{array}{l}0.040 * * * \\
(0.004)\end{array}$ & $\begin{array}{l}0.04 * * * \\
(0.004)\end{array}$ \\
\hline Experience2 & $\begin{array}{l}-0.004 * * * \\
(0.000)\end{array}$ & $\begin{array}{l}-0.003 * * * \\
(0.000)\end{array}$ & $\begin{array}{l}-0.001 * * * \\
(0.000)\end{array}$ & $\begin{array}{l}-0.001 * * * \\
(0.000)\end{array}$ \\
\hline Half populated & $\begin{array}{l}-0.073 \\
(0.066)\end{array}$ & $\begin{array}{l}-0.068 \\
(0.065)\end{array}$ & $\begin{array}{l}-0.037 * \\
(0.019)\end{array}$ & $\begin{array}{l}-0.043^{* *} \\
(0.019)\end{array}$ \\
\hline Low populated & $\begin{array}{l}-0.102 \\
(0.064)\end{array}$ & $\begin{array}{l}-0.104^{\dagger} \\
(0.063)\end{array}$ & $\begin{array}{l}-0.132 * * * \\
(0.019)\end{array}$ & $\begin{array}{l}-0.145^{* * *} \\
(0.019)\end{array}$ \\
\hline Galicia & $\begin{array}{l}0.035 \\
(0.125)\end{array}$ & $\begin{array}{l}0.039 \\
(0.124)\end{array}$ & $\begin{array}{l}-0.135^{* * *} \\
(0.035)\end{array}$ & $\begin{array}{l}-0.141^{* * * *} \\
(0.034)\end{array}$ \\
\hline Asturias & $\begin{array}{l}0.047 \\
(0.144)\end{array}$ & $\begin{array}{l}-0.006 \\
(0.144)\end{array}$ & $\begin{array}{l}-0.107^{* * *} \\
(0.035)\end{array}$ & $\begin{array}{l}-0.108^{* * * *} \\
(0.035)\end{array}$ \\
\hline Cantabria & $\begin{array}{l}-0.049 \\
(0.174)\end{array}$ & $\begin{array}{l}-0.086 \\
(0.173)\end{array}$ & $\begin{array}{l}-0.235^{* * *} \\
(0.045)\end{array}$ & $\begin{array}{l}-0.235^{* * *} \\
(0.046)\end{array}$ \\
\hline País Vasco & $\begin{array}{l}0.073 \\
(0.131)\end{array}$ & $\begin{array}{l}0.061 \\
(0.131)\end{array}$ & $\begin{array}{l}-0.011 \\
(0.035)\end{array}$ & $\begin{array}{l}-0.018 \\
(0.035)\end{array}$ \\
\hline Navarra & $\begin{array}{l}0.026 \\
(0.144)\end{array}$ & $\begin{array}{l}0.032 \\
(0.143)\end{array}$ & $\begin{array}{l}0.049 \\
(0.036)\end{array}$ & $\begin{array}{l}0.049 \\
(0.036)\end{array}$ \\
\hline
\end{tabular}


Table 13 (continued)

\begin{tabular}{|c|c|c|c|c|}
\hline & \multicolumn{2}{|l|}{2005} & \multicolumn{2}{|l|}{2011} \\
\hline & Fathers & Mothers & Fathers & Mothers \\
\hline La Rioja & $\begin{array}{l}-0.248 \\
(0.155)\end{array}$ & $\begin{array}{l}-0.299^{\dagger} \\
(0.154)\end{array}$ & $\begin{array}{l}-0.152 * * * \\
(0.042)\end{array}$ & $\begin{array}{l}-0.155^{* * *} \\
(0.042)\end{array}$ \\
\hline \multirow[t]{3}{*}{ Aragón } & $\begin{array}{l}-0.039 \\
(0.132)\end{array}$ & $\begin{array}{l}-0.084 \\
(0.134)\end{array}$ & $\begin{array}{l}-0.092^{* * * *} \\
(0.035)\end{array}$ & $\begin{array}{l}-0.096^{* * * *} \\
(0.035)\end{array}$ \\
\hline & \multicolumn{2}{|l|}{2005} & \multicolumn{2}{|l|}{2011} \\
\hline & Fathers & Mothers & Fathers & Mothers \\
\hline Castilla y León & $\begin{array}{l}0.027 \\
(0.13)\end{array}$ & $\begin{array}{l}-0.01 \\
(0.128)\end{array}$ & $\begin{array}{l}-0.109 * * * \\
(0.031)\end{array}$ & $\begin{array}{l}-0.121 * * * \\
(0.032)\end{array}$ \\
\hline Castilla La Mancha & $\begin{array}{l}-0.09 \\
(0.137)\end{array}$ & $\begin{array}{l}-0.118 \\
(0.137)\end{array}$ & $\begin{array}{l}-0.079 * * \\
(0.039)\end{array}$ & $\begin{array}{l}-0.082^{* * *} \\
(0.039)\end{array}$ \\
\hline Extremadura & $\begin{array}{l}0.222 \\
(0.152)\end{array}$ & $\begin{array}{l}0.269^{\dagger} \\
(0.151)\end{array}$ & $\begin{array}{l}-0.179 * * * \\
(0.045)\end{array}$ & $\begin{array}{l}-0.171^{* * * *} \\
(0.045)\end{array}$ \\
\hline Cataluña & $\begin{array}{l}-0.062 \\
(0.107)\end{array}$ & $\begin{array}{l}-0.086 \\
(0.108)\end{array}$ & $\begin{array}{l}-0.058^{* *} \\
(0.025)\end{array}$ & $\begin{array}{l}-0.064^{* *} \\
(0.025)\end{array}$ \\
\hline C. Valenciana & $\begin{array}{l}-0.34 * * \\
(0.117)\end{array}$ & $\begin{array}{l}-0.355^{* *} \\
(0.117)\end{array}$ & $\begin{array}{l}-0.202 * * * \\
(0.03)\end{array}$ & $\begin{array}{l}-0.209 * * * \\
(0.03)\end{array}$ \\
\hline Islas Baleares & $\begin{array}{l}0.096 \\
(0.141)\end{array}$ & $\begin{array}{l}0.088 \\
(0.141)\end{array}$ & $\begin{array}{l}-0.125^{* * *} \\
(0.038)\end{array}$ & $\begin{array}{l}-0.125^{* * *} \\
(0.039)\end{array}$ \\
\hline Andalucía & $\begin{array}{l}-0.052 \\
(0.112)\end{array}$ & $\begin{array}{l}-0.043 \\
(0.112)\end{array}$ & $\begin{array}{l}-0.284 * * * \\
(0.033)\end{array}$ & $\begin{array}{l}-0.275^{* * *} \\
(0.033)\end{array}$ \\
\hline Murcia & $\begin{array}{l}-0.366^{*} \\
(0.148)\end{array}$ & $\begin{array}{l}-0.413 * * \\
(0.149)\end{array}$ & $\begin{array}{l}-0.176^{* * *} \\
(0.039)\end{array}$ & $\begin{array}{l}-0.191 * * * \\
(0.039)\end{array}$ \\
\hline Canarias & $\begin{array}{l}0.256^{\dagger} \\
(0.132)\end{array}$ & $\begin{array}{l}0.224^{\dagger} \\
(0.132)\end{array}$ & $\begin{array}{l}-0.219 * * * \\
(0.041)\end{array}$ & $\begin{array}{l}-0.227 * * * \\
(0.040)\end{array}$ \\
\hline Sample size & 13,243 & 13,626 & 9165 & 9192 \\
\hline $\mathrm{F}$ & 169.00 & 173.27 & 93.74 & 91.49 \\
\hline Prob $>F$ & 0.000 & 0.000 & 0.000 & 0.000 \\
\hline $\mathrm{R}^{2}$ & 0.362 & 0.36 & 0.3 & 0.29 \\
\hline
\end{tabular}

(1) Dummy of educational level: 1 = uneducated, $2=$ low educational level; $3=$ medium educational level; $4=$ high educational level. (2) Dummy of gender: $0=$ man; $1=$ women. (3) Dummy of type of contract: $0=$ temporal contract, $1=$ permanent contract. (4) Dummy of country of birth: $0=$ no Spain, $1=$ Spain. (5) Dummy of urbanization: $1=$ high populated, $2=$ half populated, $3=$ low populated. (6) Dummy of regions

${ }^{\dagger} \mathrm{p}<0.1 . * \mathrm{p}<0.05$. **p $<0.01$. *** $\mathrm{p}<0.001$

Source: Author's own elaboration from longitudinal LCS dataset 
Table 14 Estimation of the income logarithm with the educational levels of parents

\begin{tabular}{|c|c|c|}
\hline & 2005 & 2011 \\
\hline Low educational level of the fathers & $\begin{array}{l}0.24 * * \\
(0.836)\end{array}$ & $\begin{array}{l}0.158 * * * \\
(0.056)\end{array}$ \\
\hline Medium educational level of the fathers & $\begin{array}{l}0.497 * * * \\
(0.123)\end{array}$ & $\begin{array}{l}0.349 * * * \\
(0.061)\end{array}$ \\
\hline High educational level of the fathers & $\begin{array}{l}0.871 \text { *** } \\
(0.12)\end{array}$ & $\begin{array}{l}0.415^{* * * *} \\
(0.061)\end{array}$ \\
\hline Low educational level of the mothers & $\begin{array}{l}0.326 * * * \\
(0.081)\end{array}$ & $\begin{array}{l}0.281 * * * \\
(0.044)\end{array}$ \\
\hline Medium educational level of the mothers & $\begin{array}{l}0.665^{* * * *} \\
(0.140)\end{array}$ & $\begin{array}{l}0.307 * * * \\
(0.055)\end{array}$ \\
\hline High educational level of the mothers & $\begin{array}{l}0.606^{* * * *} \\
(0.154)\end{array}$ & $\begin{array}{l}0.387 * * * \\
(0.058)\end{array}$ \\
\hline Gender & $\begin{array}{l}-1.068^{* * *} \\
(0.049)\end{array}$ & $\begin{array}{l}-0.246^{* * *} \\
(0.014)\end{array}$ \\
\hline Age & $\begin{array}{l}-0.435^{* * *} \\
(0.026)\end{array}$ & $\begin{array}{l}-0.017 * \\
(0.01)\end{array}$ \\
\hline Edad2 & $\begin{array}{l}0,003 * * * \\
(0.000)\end{array}$ & $\begin{array}{l}0.000 * \\
(0.000)\end{array}$ \\
\hline Type of contract & $\begin{array}{l}1.126 * * * \\
(0.063)\end{array}$ & $\begin{array}{l}0.613^{* * * *} \\
(0.021)\end{array}$ \\
\hline Country of birth & $\begin{array}{l}0.193 \\
(0.118)\end{array}$ & $\begin{array}{l}-0.207^{* * *} \\
(0.025)\end{array}$ \\
\hline Experience & $\begin{array}{l}0.323 * * * \\
(0.016)\end{array}$ & $\begin{array}{l}0.041^{* * *} \\
(0.004)\end{array}$ \\
\hline Experience2 & $\begin{array}{l}-0.004 * * * \\
(0.000)\end{array}$ & $\begin{array}{l}-0.001^{* * * *} \\
(0.000)\end{array}$ \\
\hline Half populated & $\begin{array}{l}-0.0636 \\
(0.067)\end{array}$ & $\begin{array}{l}-0.035^{*} \\
(0.019)\end{array}$ \\
\hline Low populated & $\begin{array}{l}-0.092 \\
(0.064)\end{array}$ & $\begin{array}{l}-0.127^{* * *} \\
(0.019)\end{array}$ \\
\hline Galicia & $\begin{array}{l}0.041 \\
(0.127)\end{array}$ & $\begin{array}{l}-0.136^{* * *} \\
(0.035)\end{array}$ \\
\hline Asturias & $\begin{array}{l}0.017 \\
(0.146)\end{array}$ & $\begin{array}{l}-0.112 * * * \\
(0.035)\end{array}$ \\
\hline Cantabria & $\begin{array}{l}-0.079 \\
(0.175)\end{array}$ & $\begin{array}{l}-0.242 * * * \\
(0.0454)\end{array}$ \\
\hline \multirow[t]{2}{*}{ País Vasco } & $\begin{array}{l}0.051 \\
(0.133)\end{array}$ & $\begin{array}{l}0.0202 \\
(0.035) \\
\end{array}$ \\
\hline & 2005 & 2011 \\
\hline Navarra & $\begin{array}{l}0.007 \\
(0.146)\end{array}$ & $\begin{array}{l}0.043 \\
(0.0358)\end{array}$ \\
\hline La Rioja & $\begin{array}{l}-0.254 \\
(0.155)\end{array}$ & $\begin{array}{l}-0.155^{\text {**** }} \\
(0.041)\end{array}$ \\
\hline Aragón & $\begin{array}{l}-0.455 \\
(0.134)\end{array}$ & $\begin{array}{l}-0.096^{* * *} \\
(0.035)\end{array}$ \\
\hline Castilla y León & $\begin{array}{l}0.011 \\
(0.131)\end{array}$ & $\begin{array}{l}-0.117^{* * *} \\
(0.031)\end{array}$ \\
\hline Castilla La Mancha & $\begin{array}{l}0.079 \\
(0.137)\end{array}$ & $\begin{array}{l}-0.074 * \\
(0.039)\end{array}$ \\
\hline Extremadura & $\begin{array}{l}0.261^{\dagger} \\
(0.153)\end{array}$ & $\begin{array}{l}-0.174^{* * * *} \\
(0.045)\end{array}$ \\
\hline Cataluña & $\begin{array}{l}-0.046 \\
(0.108)\end{array}$ & $\begin{array}{l}-0.050 * \\
(0.025)\end{array}$ \\
\hline
\end{tabular}


Table 14 (continued)

\begin{tabular}{lll}
\hline & 2005 & 2011 \\
\hline C. Valenciana & $-0.337^{* *}$ & $-0.207^{* * *}$ \\
& $(0.03)$ & $-0.128^{* * *}$ \\
Islas Baleares & $(0.119)$ & $(0.038)$ \\
& 0.105 & $-0.272^{* * *}$ \\
Andalucía & $(0.142)$ & $(0.032)$ \\
Murcia & -0.021 & $-0.181^{* * *}$ \\
Canarias & $(0.113)$ & $(0.039)$ \\
Sample size & $-0.356^{* *}$ & $-0.217^{* * *}$ \\
F & $(0.151)$ & $(0.040)$ \\
Prob $>$ F & $0.279^{* *}$ & 9161 \\
$\mathrm{R}^{2}$ & $(0.134)$ & 86.98 \\
\hline
\end{tabular}

(1) Dummy of educational level: $1=$ uneducated, $2=$ low educational level; $3=$ medium educational level; $4=$ high educational level. (2) Dummy of economic situation: 1 =bad economic situation, $2=$ intermediate economic situation, $3=$ good economic situation. (3) Dummy of gender: $0=$ man; $1=$ women. (4) Dummy of type of contract: $0=$ temporal contract, $1=$ permanent contract. (5) Dummy of country of birth: $0=$ no Spain, $1=$ Spain. (6) Dummy of urbanization: $1=$ high populated, $2=$ half populated, $3=$ low populated. (7) Dummy of regions

$\dagger<0.1 . * \mathrm{p}<0.05$. **p $<0.01 . * * * \mathrm{p}<0.001$

Source: Author's own elaboration from longitudinal LCS dataset 
Table 15 Estimation of the income logarithm with the educational levels of parents and economic situation

\begin{tabular}{|c|c|c|}
\hline & 2005 & 2011 \\
\hline Low educational level of the fathers & $\begin{array}{l}0.219^{* *} \\
(0.085)\end{array}$ & $\begin{array}{l}0.129 * * \\
(0.055)\end{array}$ \\
\hline Medium educational level of the fathers & $\begin{array}{l}0.456 * * * \\
(0.124)\end{array}$ & $\begin{array}{l}0.309 * * * \\
(0.060)\end{array}$ \\
\hline High educational level of the fathers & $\begin{array}{l}0.825^{* * * *} \\
(0.121)\end{array}$ & $\begin{array}{l}0.359 * * * \\
(0.061)\end{array}$ \\
\hline Low educational level of the mothers & $\begin{array}{l}0.309 * * * \\
(0.081)\end{array}$ & $\begin{array}{l}0.259 * * * \\
(0.044)\end{array}$ \\
\hline Medium educational level of the mothers & $\begin{array}{l}0.640 * * * \\
(0.142)\end{array}$ & $\begin{array}{l}0.283 * * * \\
(0.056)\end{array}$ \\
\hline High educational level of the mothers & $\begin{array}{l}0.585^{* * *} \\
(0.156)\end{array}$ & $\begin{array}{l}0.343 * * * \\
(0.059)\end{array}$ \\
\hline Bad situation & $\begin{array}{l}-0.090 \\
(0.076)\end{array}$ & $\begin{array}{l}-0.134^{* * * *} \\
(0.025)\end{array}$ \\
\hline Good situation & $\begin{array}{l}0.118^{\dagger} \\
(0.063)\end{array}$ & $\begin{array}{l}0.072 * * * \\
(0.016)\end{array}$ \\
\hline Gender & $\begin{array}{l}-1-067 * * * \\
(0.05)\end{array}$ & $\begin{array}{l}-0.243^{* * * *} \\
(0.014)\end{array}$ \\
\hline Age & $\begin{array}{l}-0.438 * * * \\
(0.026)\end{array}$ & $\begin{array}{l}-0.013 \\
(0.01)\end{array}$ \\
\hline Edad2 & $\begin{array}{l}0.003 * * * \\
(0.000)\end{array}$ & $\begin{array}{l}0.000 \\
(0.000)\end{array}$ \\
\hline Type of contract & $\begin{array}{l}1.112 * * * \\
(0.063)\end{array}$ & $\begin{array}{l}0.604 * * * \\
(0.021)\end{array}$ \\
\hline Country of birth & $\begin{array}{l}0.169 \\
(0.119)\end{array}$ & $\begin{array}{l}0.196 * * * \\
(0.026)\end{array}$ \\
\hline Experience & $\begin{array}{l}0.32206 * * * \\
(0.011)\end{array}$ & $\begin{array}{l}0.039 * * * \\
(0.004)\end{array}$ \\
\hline Experience2 & $\begin{array}{l}-0.004 * * * \\
(0.000)\end{array}$ & $\begin{array}{l}-0.001 * * * \\
(0.000)\end{array}$ \\
\hline Half populated & $\begin{array}{l}-0.064 \\
(0.067)\end{array}$ & $\begin{array}{l}-0.131 * * \\
(0.02)\end{array}$ \\
\hline Low populated & $\begin{array}{l}-0.090 \\
(0.065)\end{array}$ & $\begin{array}{l}-0.040^{* * * *} \\
(0.019)\end{array}$ \\
\hline Galicia & $\begin{array}{l}0.096 \\
(0.129)\end{array}$ & $\begin{array}{l}-0.128^{* * * *} \\
(0.035)\end{array}$ \\
\hline \multirow[t]{2}{*}{ Asturias } & $\begin{array}{l}0.035 \\
(0.148)\end{array}$ & $\begin{array}{l}-0.115^{\text {**** }} \\
(0.036)\end{array}$ \\
\hline & 2005 & 2011 \\
\hline Cantabria & $\begin{array}{l}-0.062 \\
(0.177)\end{array}$ & $\begin{array}{l}-0.231^{* * * *} \\
(0.047)\end{array}$ \\
\hline País Vasco & $\begin{array}{l}0.085 \\
(0.135)\end{array}$ & $\begin{array}{l}-0.023 \\
(0.036)\end{array}$ \\
\hline Navarra & $\begin{array}{l}0.016 \\
(0.149)\end{array}$ & $\begin{array}{l}0.053 \\
(0.036)\end{array}$ \\
\hline La Rioja & $\begin{array}{l}-0.248 \\
(0.158)\end{array}$ & $\begin{array}{l}-0.147^{* * * *} \\
(0.043)\end{array}$ \\
\hline Aragón & $\begin{array}{l}-0.029 \\
(0.137)\end{array}$ & $\begin{array}{l}-0.106^{* * *} \\
(0.035)\end{array}$ \\
\hline Castilla y León & $\begin{array}{l}0.027 \\
(0.133)\end{array}$ & $\begin{array}{l}-0.101^{* * * *} \\
(0.032)\end{array}$ \\
\hline Castilla La Mancha & $\begin{array}{l}-0.076 \\
(0.139)\end{array}$ & $\begin{array}{l}-0.071 * * * \\
(0.039)\end{array}$ \\
\hline
\end{tabular}


Table 15 (continued)

\begin{tabular}{|c|c|c|}
\hline & 2005 & 2011 \\
\hline Extremadura & $\begin{array}{l}0.28^{\dagger} \\
(0.155)\end{array}$ & $\begin{array}{l}-0.148^{*} \\
(0.045)\end{array}$ \\
\hline Cataluña & $\begin{array}{l}-0.026 \\
(0.110)\end{array}$ & $\begin{array}{l}-0.044 * * * \\
(0.025)\end{array}$ \\
\hline C. Valenciana & $\begin{array}{l}-0.327^{* *} \\
(0.121)\end{array}$ & $\begin{array}{l}-0.215^{*} \\
(0.030)\end{array}$ \\
\hline Islas Baleares & $\begin{array}{l}0.143 \\
(0.145)\end{array}$ & $\begin{array}{l}-0.121^{* * *} \\
(0.039)\end{array}$ \\
\hline Andalucía & $\begin{array}{l}0.006 \\
(0.115)\end{array}$ & $\begin{array}{l}-0.26 * * * \\
(0.033)\end{array}$ \\
\hline Murcia & $\begin{array}{l}-0.331 * \\
(0.153)\end{array}$ & $\begin{array}{l}-0.158^{* * *} \\
(0.04)\end{array}$ \\
\hline Canarias & $\begin{array}{l}0.320^{*} \\
(0.136)\end{array}$ & $\begin{array}{l}-0.205^{* * *} \\
(0.041)\end{array}$ \\
\hline Sample size & 12,883 & 8897 \\
\hline $\mathrm{F}$ & 141.46 & 91.70 \\
\hline Prob $>F$ & 0.000 & 0.000 \\
\hline $\mathrm{R}^{2}$ & 0.363 & 0.304 \\
\hline
\end{tabular}

(1) Dummy of gender: $0=$ man; $1=$ women. (2) Dummy of educational level: 1 =uneducated, $2=$ low educational level; $3=$ medium educational level; $4=$ high educational level. (3) Dummy of type of contract: $0=$ temporal contract, $1=$ permanent contract. (4) Dummy of country of birth: $0=$ no Spain, $1=$ Spain. (5) Dummy of urbanization: $1=$ high populated, $2=$ half populated, $3=$ low populated. (6) Dummy of regions

Source: Author's own elaboration from longitudinal LCS dataset

$\dagger<0.1 .{ }^{*} \mathrm{p}<0.05$. **p $<0.01 . * * * \mathrm{p}<0.001$

Funding Open Access funding provided thanks to the CRUE-CSIC agreement with Springer Nature. Consejería de Educación, Cultura y Deporte, Junta de Comunidades de Castilla-La Mancha (FEDER). Award Number: SBPLY/19/180501/000132 I Recipient: Carmelo Garcia. Consejería de Educación, Juventud y Deporte, Comunidad de Madrid. Award Number: H2019/HUM-5793 - OPINBI "Igualdad de oportunidades, inclusión social y bienestar" (2019-2022) I Recipient: Carmelo Garcia.

Data Availability The data that support the findings of this study are available in Instituto Nacional de Estadística [https://www.ine.es/] [INEbase / Nivel y condiciones de vida (IPC) / Condiciones de vida / Encuesta de condiciones de vida / Resultados / Módulos anuales].

\section{Declarations}

Conflict of interest The authors declare that they have no conflict of interest.

Ethical approval This research does not involve human participants and/or animals.

Informed consent Informed consent is not necessary.

Open Access This article is licensed under a Creative Commons Attribution 4.0 International License, which permits use, sharing, adaptation, distribution and reproduction in any medium or format, as long as you give appropriate credit to the original author(s) and the source, provide a link to the Creative Commons licence, and indicate if changes were made. The images or other third party material in this article are included in the article's Creative Commons licence, unless indicated otherwise in a credit line to the material. If material is not included in the article's Creative Commons licence and your intended use is not permitted by statutory regulation or exceeds the permitted use, you will need to obtain permission directly from the copyright holder. To view a copy of this licence, visit http://creativecommons.org/licenses/by/4.0/.

\section{References}

Aaberge, R. \& Mogstad, M. (2014). Income Mobility as an Equalizer of Permanent Income. Discussion Paper 769, Statistics Norway, Research Department. https://econpapers.repec.org/paper/ssbdi spap/769.htm

Atkinson, A. (1981). On intergenerational income mobility in Britain. Journal of Post Keynesian Economics, 3(2), 194-2018. https:// www.jstor.org/stable/4537588

Ayala, L. (2016). La desigualdad en España: fuentes, tendencias y comparaciones internacionales. Estudios sobre la Economía Española, 2016, 61. FEDEA. https://documentos.fedea.net/pubs/eee/ eee2016-24.pdf

Ayala, L., \& Sastre, M. (2002). La medición de la movilidad de ingresos: enfoques e indicadores. Hacienda Pública Españolal Revista de Economía Pública, 162(3), 101-131. https://docum entos.fedea.net/pubs/eee/eee2016-24.pdf

Bárcena, E., \& Moro, A. (2013). Movilidad de los ingresos en España: el efecto de la crisis. Papeles de Economía Española, 135, 202-216. https://www.funcas.es/articulos/movilidad-delos-ingresos-en-espana-el-efecto-de-la-crisis/

Becker, G., \& Tomes, N. (1986). Human capital and the rise and fall of families. Journal of Labor Economics, 4(3), 2-39.https:// www.jstor.org/stable/2534952 
Behrman, J. R., \& Taubman, P. (1990). The intergenerational correlation between children's adult earnings and their parents' income: results from the Michigan panel survey of income dynamics. Review of Income and Wealth, 36(2), 115-127. http:// www.roiw.org/1990/115.pdf

Bratsberg, B., Roed, K., Raaum, O., Naylor, R., Jäntti, M., Eriksson, T., \& Österbacka, E. (2007). Nonlinearities in intergenerational earnings mobility: Consequences for cross-country comparisons. The Economic Journal, 117(519), C72-C92. https://doi. org/10.1111/j.1468-0297.2007.02036.x

Bratberg, E., Davis, J., Mazumder, B., Nybom, M., Schnitzlein, D. D., \& Vaage, K. (2017). A comparison of intergenerational mobility curves in Germany, Norway, Sweden, and the US. The Scandinavian Journal of Economics, 119(1), 72-101. https:// doi.org/10.1111/sjoe. 12197

Cantó, O. (2000). Income mobility in Spain: How much is there? Review of Income and Wealth, 46(1), 85-102. https://doi.org/ 10.1111/j.1475-4991.2000.tb00392.x

Celorrio, X. (2013). Tendencias de movilidad y reproducción social por la educación en España. RASE, 6, 32-48. https://ojs.uv.es/ index.php/RASE/article/view/8596

Cervini, M. (2015). Intergenerational earnings and income mobility in Spain. Review of Income and Wealth, 61(2015), 812-828. https://doi.org/10.1111/roiw.12130

Corak, M., \& Heisz, A. (1999). The intergenerational earnings and income mobility of Canadian men: Evidence from longitudinal income tax data. Journal of Human Resources, 34, 504-533. https://www.jstor.org/stable/146378

Corak, M., Lindquist, M. J., \& Mazumder, B. (2014). A comparison of upward and downward intergenerational mobility in Canada, Sweden and the US. Labour Economics, 30, 185-200. https:// doi.org/10.1016/j.labeco.2014.03.013

Cueto, B. (2015). Causalidad en la transmisión intergeneracional de la pobreza en España. XXII Encuentro de Economía Pública, Universidad de Vigo. https://dialnet.unirioja.es/descarga/artic ulo/5690694.pdf

Dearden, L., Machin, S., \& Reed, H. (1997). Intergenerational mobility in Britain. The Economic Journal, 107, 47-66. https://www. jstor.org/stable/2235270

Fertig, A. R. (2003). Trends in intergenerational earnings mobility in the United States. Journal of Income Distribution, 12(3-4), 108-130. https://jid.journals.yorku.ca/index.php/jid/article/ view/1271

Fortin, N. M. \& Lefebvre S. (1998). Intergenerational Income Mobility in Canada. Labour Markets, Social Institutions and the Future of Canada's Children, 89-553. https://www150.statcan.gc.ca/n1/en/ catalogue/89-553-X19980014020

Gil, C. J., Marqués, I., \& Fachelli, S. (2017). Intergenerational social mobility in Spain between 1956 and 2011: The role of educational expansion and economic modernisation in a late industrialised country. Research in Social Stratification and Mobility, 51, 14-27. https://doi.org/10.1016/j.rssm.2017.06.002

Güell, M., Mora, J. \& Telmer, C. (2007). Intergenerational mobility and the informative content of surnames. CEPR Discussion Paper, No. DP6316. https://repec.cepr.org/repec/cpr/ceprdp/DP6316.pdf

Hertz, T. N. (2001). Education, inequality and economic mobility in South Africa. Doctoral Dissertations Available from Proquest. https://scholarworks.umass.edu/dissertations/AAI3027205

Jäntti, M., Bratsberg, B., Roed, K., Raaum, O., Naylor, R., Österbacka, E., Bjorklund, A. \& Eriksson, T. (2006). American exceptionalism in a new light: A comparison of intergenerational earnings mobility in the Nordic Countries, the United
Kingdom and the United States. IZA DP, No. 1938. https://ftp. iza.org/dp1938.pdf

Jäntti, M., \& Jenkins, S. P. (2015). Income mobility. Handbook of income distribution, (Vol. 2, pp. 807-935). Elsevier.

Jenkins, S. P., \& Siedler, T. (2007). The intergenerational transmission of poverty in industrialized countries. Chronic poverty Research Centre Working Paper, 75. https://doi.org/10.2139/ssrn.1752983

Lillard, L. A. \& Kilburn M. R. (1995). Intergenerational earnings links: Sons and daughters. Unpublished.

McMurrer, D. P., Condon, M. \& Sawhill, I. V. (1997). Intergenerational mobility in the United States. Urban Institute. http://webarchive. urban.org/publications/406796.html

Narayan, A., Van Der Weide, R., Cojocaru, A., Lakner, C., Redaelli, S., Mahler, D. G., Nichanametla Ramasubbaiah, R. G. \& Thewissen, S.H. (2018). Fair progress?: Economic mobility across generations around the world. The World Bank. http://hdl.handle.net/ $10986 / 28428$

Nilsson, W. (2019). Estimating nonlinear intergenerational income mobility with correlation curves. Economics: The Open-Access, Open-Assessment E-Journal, 13(2019-7), 1-20. http://www.econo mics-ejournal.org/economics/journalarticles/2019-7/

OECD. (2018). Broken social elevator?: how to promote social mobility. OECD Publishing, Paris. https://www.oecd.org/social/soc/ Social-mobility-2018-Overview-MainFindings.pdf

Österberg, T. (2000). Intergenerational income mobility in Sweden: $¿$ What do tax-data show? The Review of Income and Wealth, 46(4), 421-436. https://doi.org/10.1111/j.1475-4991.2000.tb004 09. $\mathrm{x}$

Pascual, M. (2009). Intergenerational income mobility: The transmission of socio-economic status in Spain. Journal of Policy Modeling, 31(6), 835-846. https://doi.org/10.1016/j.jpolmod.2009. 07.004

Prais, S. J. (1955). Measuring social mobility. Journal of the Royal Statistical Society Series A, 118, 56-66.

Prieto, J., Salas, R. y Alvarez, S. (2002). Movilidad social y desigualdad económica. Instituto de Estudios Fiscales, working paper. https://dialnet.unirioja.es/servlet/articulo?codigo $=211379$

Requena, M. (2016). El ascensor social ¿Hasta qué punto una mejor educación garantiza una mejor posición social?. Observatorio social de la Caixa. Recuperado el día 27/06/2019 de: https://obser vatoriosociallacaixa.org/-/el-ascensor-social-hasta-que-punto-unamejor-educacion-garantiza-una-mejor-posicion-social-

Sánchez, A. (2004). Movilidad intergeneracional de ingresos y educativa en España (1980-90). IEB Working Paper, 2004/01. https:// ieb.ub.edu/en/publication/2004-01-movilidad-intergeneracionalde-ingresos-y-educativa-en-espana-1980-90/

Shorrocks, A. F. (1978). The measurement of mobility. Econometrica, 46, 1013-1024. https://www.jstor.org/stable/1911433

Solon, G. (1992). Intergenerational income mobility in the United States. American Economic Review, 82(3), 393-408. https://www. jstor.org/stable/2117312

Tormo, V. , Lahiguera, L., \& Guillén, A. (2016).Cuentas de la educación en España, 2000-2013.: Recursos, gastos y resultados. Fundación BBVA. https://www.fbbva.es/en/publicaciones/lascuentas-de-la-educacion-en-espana-2000-2013-recursos-gastosy-resultados-2/

Zimmerman, D. (1992). Regression toward mediocrity in economic stature. American Economic Review, 82(3), 409-429. https:// www.jstor.org/stable/2117313

Publisher's Note Springer Nature remains neutral with regard to jurisdictional claims in published maps and institutional affiliations. 